\title{
ANÁlISE DA RELAÇÃO ENTRE $O$ DIREITO AO MEIO AMBIENTE ECOLOGICAMENTE EQUILIBRADO E O DIREITO À MANIFESTAÇÃO CULTURAL NA VAQUEJADA APÓS A EMENDA CONSTITUCIONAL 96/17
}

ANALYSIS OF THE RELATIONSHIP BETWEEN THE RIGHT TO THE ENVIRONMENTALLY BALANCED ENVIRONMENT AND THE RIGHT TO CULTURAL MANIFESTATION IN VAQUEJADA AFTER CONSTITUTIONAL AMENDMENT 96/17

\author{
Renata Rodrigues de Castro Rocha ${ }^{1}$
}

Felipe Alves Bittencourt ${ }^{2}$

\section{RESUMO}

O presente artigo tem como objetivo analisar o direito da pessoa humana ao meio ambiente ecologicamente equilibrado, bem como a proteção jurídica aos animais inseridos na prática da vaquejada em face ao direito à manifestação cultural após a implementação da emenda constitucional 96 de 2017. Esta emenda acrescentou o § 7응 ao artigo 225 da Constituição Federal que passou a vigorar reconhecendo como não cruéis práticas desportivas que utilizem animais desde que sejam manifestações culturais. Ressalta-se que em 2016 o Supremo Tribunal Federal declarou inconstitucional a Lei cearense $15.299 / 13$ que regulamentava a vaquejada por considerá-la cruel. Portanto desponta um conflito aparente entre regramentos constitucionais. A pesquisa foi desenvolvida por meio do método dialético que busca através de argumentos fundamentados estabelecer o entendimento mais adequado às divergências jurídicas encontradas em relação à regulamentação da vaquejada. Após a pesquisa, concluiu-se que as novas legislações criadas para regulamentar a vaquejada possuem aspecto inconstitucional, pois juntas manifestam o interesse de tutelar prática que maltrata animais, portanto incompatível com meio ambiente ecologicamente equilibrado, direito fundamental de terceira geração que constitui cláusula pétrea, portanto não é susceptível à alteração.

Palavras-chave: Crueldade aos animais; Direito à cultura; Vaquejada.

\footnotetext{
${ }^{1}$ Doutora e Mestre em Ciência Florestal pela Universidade Federal de Viçosa - UFV, Minas Gerais. Professora Adjunta do curso de Direito da Universidade Federal do Tocantins - UFT. E-mail: renatarocha@uft.edu.br ORCID 0000-0002-9247-7724

${ }^{2}$ Bacharel em Direito. E-mail: felipewzr65@gmail.com ORCID. https://orcid.org/0000-0002-8317-7308
} 


\begin{abstract}
This article aims to analyze the human right to the environment as well as the legal protection of animals in the practice of vaquejada (bull-catching) facing the right to cultural manifestation after the implementation of constitutional amendment 96 of 2017. This amendment added the $\S 7$ to article 225 of the Federal Constitution that came into force recognizing as non-cruel practices of sports that use animals as long as they are cultural manifestations. We emphasize that in 2016 the Supreme Federal Court declared unconstitutional Ceará's Law 15.299/13 that regulated vaquejada by considering it as cruel. So it dawns an apparent conflict between constitutional rules. The research was developed through the dialectical method that seeks through grounded arguments to establish the most appropriate understanding to the legal differences found in regarding the regulation of the vaquejada. It was concluded that the new legislations created to regulate the vaquejada have unconstitutional aspect, because together they express the interest of protecting practice that abuses animals, therefore incompatible with ecologically balanced environment, fundamental right of third generation that constitutes stone clause, therefore not susceptible to change
\end{abstract}

Keywords: Cruelty to animals; Right to culture; Vaquejada (bull catching).

\title{
1. INTRODUÇÃO
}

A presente pesquisa aborda o direito da pessoa humana ao meio ambiente ecologicamente equilibrado e a tutela jurídica dos animais inseridos na prática da Vaquejada, atividade que traz em sua essência a possibilidade de maus tratos a bovinos e equinos.

O trabalho foi motivado pela necessidade de verificar a proteção jurídica aos animais em práticas, tidas como tradição regional, capazes de infligir thes sofrimento. Ganha destaque no aspecto moral, onde se têm seres capazes de sentir dor, mas que não podem reclamar o direito de não sofrer, os quais dependem exclusivamente da conscientização humana para que não recebam tratamento inadequado.

A Constituição de 1988 garante a todos o acesso aos direitos culturais, valorizando e difundindo as manifestações culturais, por outro lado define que o Poder Público deve proteger a fauna e a flora, vedadas as práticas que provoquem a extinção de espécies ou submetam os animais à crueldade, conforme preconiza 0 art.225, §1ํㅡ, VII da Constituição Federal. 
As Vaquejadas são consideradas tradição no Brasil, em especial na região nordeste, onde é tida como manifestação da cultura local. No estado do Ceará, ela foi regulamentada através da Lei 15.299 em 2013. À época a Procuradoria Geral da República (PGR) entendeu que a prática normatizada, trazia em sua essência indícios de crueldade com os animais envolvidos, portanto incompatível com o art. 225 da Constituição. Em virtude deste posicionamento, a PGR interpôs junto ao Supremo Tribunal Federal (STF) a Ação Direta de Inconstitucionalidade (ADI) 4983/CE arguindo a lei cearense $15.299 / 2013$ no sentido de declarar inconstitucional a prática da Vaquejada.

Em 2016, o Supremo Tribunal, por maioria e nos termos do voto do Relator, julgou procedente o pedido formulado para declarar a inconstitucionalidade da Lei $n^{\circ}$ 15.299/2013 do Estado do Ceará, ou seja, a normatização da Vaquejada se tornou incompatível com a Constituição.

Por se tratar de uma atividade com forte influência econômica e cultural, houve uma reação legislativa no sentido de legitimar o tema já declarado inconstitucional. Para tanto, em 2016 foi criada e sancionada sem vetos a Lei Federal 13.364/16 que reconheceu a Vaquejada, os rodeios e as provas de laço como manifestação cultural e patrimônio imaterial cultural brasileiro.

Somada à Lei 13.364/16, promulgou-se a Emenda Constitucional (EC) 96/17 a qual dispõe que não se consideram cruéis as práticas desportivas que utilizem animais, desde que sejam manifestações culturais, registradas como bem de natureza imaterial integrante do patrimônio cultural brasileiro, devendo ser regulamentadas ações que assegurem o bem-estar dos animais por lei específica.

Ou seja, reconheceu-se por lei o aspecto cultural da Vaquejada, e inseriu-se no artigo 225, uma cláusula de exceção que admite a crueldade contra animais. Pois o legislador considerou que não existe crueldade somente pelo fato de as práticas terem o seu caráter cultural reconhecido. Apesar de a E.C. 96 prever que a lei deve assegurar o bem-estar do animal, não se demonstrou uma forma precisa de fazê-lo sem desfigurar a prática.

Logo, desponta um conflito aparente entre o teor da Emenda Constitucional 96 e os termos do artigo $225, \S 1^{\circ}$, inciso VII, o qual trata o meio ambiente ecologicamente 
equilibrado como bem ambiental reconhecido como direito fundamental de terceira geração que veda práticas que submetam animais à crueldade.

Para se alcançar a conclusão utilizou-se o método dialético para estabelecer através de argumentos fundamentados o entendimento mais adequado às divergências encontradas quanto à regulamentação da vaquejada. Utilizou-se a abordagem qualitativa e o tipo exploratório, uma vez que não houve o intuito de mensurar dados acerca da Vaquejada, e sim, analisar a fundamentação que a compatibiliza ou não com o ordenamento jurídico. Assim, a pesquisa fui classificada como levantamento bibliográfico de doutrinas no âmbito constitucional e ambiental e de julgados inerentes a práticas culturais que envolvam animais inclusive a própria Vaquejada.

Dentro deste contexto, o trabalho busca analisar o direito humano ao meio ambiente ecologicamente equilibrado em detrimento do direito à manifestação cultural presente na Vaquejada após a implementação da emenda constitucional 96 de 2017. Procura também debater os julgados do Supremo Tribunal Federal em matérias similares, para no fim opinar sobre a constitucionalidade ou não da referida emenda.

\section{O DIREITO À MANIFESTAÇÃO CULTURAL NO ORDENAMENTO JURÍDICO BRASILEIRO E A VAQUEJADA}

Os direitos culturais foram previstos, inicialmente, na Declaração Universal dos Direitos Humanos de 1948 a qual os qualificou como indispensáveis à dignidade e ao livre desenvolvimento da personalidade.

Em âmbito Nacional, a Constituição Federal de 1988, em seu artigo 215, prevê que o Estado garantirá a todos o pleno exercício dos direitos culturais e acesso às fontes da cultura nacional e apoiará e incentivará a valorização e a difusão das manifestações culturais.

$\mathrm{Na}$ opinião de Fernandes (2008), os direitos culturais são direitos do cidadão relacionados à cultura da sociedade da qual faz parte, que incluem a produção cultural, o acesso à cultura local e o direito à memória histórica. 
O direito à produção cultural consiste no direito de exprimir a criatividade e está relacionado à capacidade de o homem produzir e manifestar cultura, as pessoas por si só produzem cultura através dos seus hábitos e costumes.

O direito de acesso à cultura é a garantia de que todo indivíduo pode ter acesso aos bens culturais produzidos pela sociedade que o cerca. Trata-se da democratização dos bens culturais à população.

O direito à memória histórica garante que todos os homens têm o direito de ter acesso aos bens materiais e imateriais que representem o seu passado, a sua tradição e a sua História.

\subsection{A Vaquejada nordestina e sua origem}

O exercício da vaquejada originou-se como forma de reunir o gado que se distanciava das fazendas. O vaqueiro necessitava ter total controle sobre o gado para que não houvesse perdas de rebanho e fosse garantido o retorno do animal à propriedade de origem. A dominação do homem sobre o boi era demonstrada através da derrubada.

$\mathrm{Na}$ origem da vaquejada, escolhia-se um local para onde o gado seria encaminhado e em seguida prosseguia-se à apartação, ou seja, separavam-se e contavam-se os animais sob responsabilidade de determinado vaqueiro e, em seguida, devolvia-se o gado selecionado ao proprietário. Segundo Bezerra:

As vaquejadas simulam, por assim dizer, nos pátios das grandes fazendas, a útil técnica implementada nas várzeas pelos vaqueiros, objetivando arregimentar os animais (vacas, bois, touros etc.) que se desprendem dos núcleos (fazendas) onde nasceram. Nessas ocasiões, os vaqueiros que andam pelos áridos campos do sertão nordestino acomodam-se em uma fazenda pré-escolhida para promover a "apartação" do gado, e é justamente nessa oportunidade, que os fazendeiros se agrupavam para identificar os animais amontoados, promoverem a separação (apartação) e encaminharem às fazendas de onde o boi se tinha debandado por entre a caatinga. (BEZERRA, 1978, p.8)

Como caracteriza Cascudo (1976), na década de 40 do século XX, vaqueiros da região Nordeste começaram a divulgar suas habilidades através da "corrida de 
mourão", atividade que ficou conhecida pelo manuseio do gado em áreas delimitadas dentro das próprias fazendas. Ao passar o tempo, iniciou-se uma competição de derrubada de bois, onde os vaqueiros recebiam premiações ao atingir o objetivo, essa prática recebeu a denominação de vaquejada.

Considera-se a vaquejada como prática esportiva que se tornou culturalmente aceita e difundida pelo Brasil com maior predominância na região nordeste. "Trata-se do festejo mais tradicional do ciclo do gado nordestino" (CASCUDO, 1976, p.38).

$\mathrm{Na}$ opinião do autor, a derrubada do boi através da cauda, popularizou-se pelo interior do Nordeste atendendo à natureza da vegetação nas caatingas, pois, por suas próprias características físicas, as árvores e/ou arbustos que a compunham, dificultavam o lançamento do laço para dominar o animal.

Nas últimas décadas do século passado, a prática obteve considerável avanço, ganhou aspecto esportivo e ordenamento próprio. O Regulamento Geral da vaquejada da Associação Brasileira de Vaquejada de 2017 - 2018 dispõe que dois competidores a cavalo devem perseguir um boi que sai correndo em uma pista de competição, após ser liberado do local onde permanece antes do início da prova.

A missão dos vaqueiros é derrubar o boi dentro do espaço demarcado entre duas linhas feitas na arena, denominadas "faixa". Após o animal ser solto, os competidores correm lado a lado a ele. Cada um dos vaqueiros tem funções determinadas. O "vaqueiro-esteireiro" é responsável por direcionar o boi ao longo da pista, emparelhando-o com o "vaqueiro-puxador". Próximo à "faixa", o vaqueiro esteireiro recolhe a cauda do animal revestida do protetor de cauda e a entrega ao vaqueiro-puxador, para que este, tracionando-a, derrube o boi dentro do espaço demarcado.

Necessita-se que o boi desprenda as quatro patas do chão durante a derrubada para que se obtenha pontuação válida, se ocorrer este descolamento, o árbitro diz "valeu boi" e o ponto é computado, caso contrário o árbitro diz "zero boi" e a pontuação não ocorre.

Gordilho e Figueiredo (2016) definem a prática como uma demonstração de força ágil, provocadora de aplausos e criadora de fama daqueles que participavam efetivamente desses eventos públicos. Ou seja, representa a demonstração de domínio 
do homem sobre o animal de modo a conduzir este para o exato local que fora préestabelecido por aquele.

\subsection{A vaquejada e o seu aspecto econômico e cultural}

A vaquejada tornou-se um negócio de grande importância no cenário econômico, fazendo circular, anualmente, uma grande quantidade de emprego e renda para o País. A Associação Alagoana de Criadores de Cavalo Quarto de Milha - ALQM relatou que:

De acordo com o relatório, divulgado em dezembro de 2018, a prática movimenta, em média, anualmente, mais de $\mathrm{R} \$ 62$ milhões e emprega cerca de 11 mil pessoas, sendo 4800 de forma direta. Como indicado no parecer técnico, "a atividade fica à frente de importantes segmentos como a indústria químico plástica (tendo a Braskem como empresachave), da agricultura (sem contar o setor energético) e a da indústria têxtil).

Além da forte economia que gira em torno da prática, o Regulamento Geral da Vaquejada de 2017 - 2018 a considera uma atividade recreativa-competitiva, com características de esporte. No início dos anos 90, ela se transformou em uma grande festividade que atrai pessoas simpatizantes da competição e das atrações do evento que conta com a exposição de cantores locais e nacionais.

Durante as festividades são ofertados prêmios e quantias elevadas de dinheiro aos vaqueiros campeões. Considerando a ampla proteção das culturas conferida pela Constituição, não há como negar a ela o caráter de manifestação cultural tradicional. Mas o fato de a vaquejada movimentar a economia e ser uma manifestação cultural não a torna imune ao contraste com outros valores constitucionais, como a não submissão de animais à crueldade 


\section{MAUS TRATOS AOS ANIMAIS NO DIREITO BRASILEIRO}

A origem dos maus tratos aos animais se deu a partir da relação de dominação existente entre homens e animais, onde aquele se valia do domínio para fazer com que este o servisse nas atividades cotidianas.

Dias (2000) argumenta que atividades generalizadas de maus-tratos aos animais nasceram da crença bíblica de que Deus outorgou ao homem o domínio sobre todas as criaturas e do pensamento filosófico que se desenvolveu através dessa máxima a qual tem legitimado a exploração aos animais, fazendo dela atividade comum.

Ações que objetivem oferecer proteção jurídica aos animais merecem atenção pois ela está relacionada à capacidade dos animais de experimentarem sensações, definida como senciência. "Dizer que um animal é senciente significa dizer que ele tem a capacidade de sentir e que ele se importa com o que sente" (NACONECY, 2006, p.117), diante dos desafios impostos aos que reconhecem esta premissa, tem-se que animais não humanos são seres, dotados de sensibilidade e memória e que percebem o momento do desamparo, sentem dor, medo, prazer e alegria.

Ao se tratar da regulamentação brasileira sobre a proteção dos animais, verificase que se tornou ultrapassado o entendimento de que animais sejam considerados apenas como coisas sem merecer nenhuma tutela jurisdicional, prova disso é que a proteção à fauna vem sendo garantida por documentos normativos no decorrer do século passado como: a Lei de Proteção à Fauna, Lei no 5197/67; Código de Pesca, decreto-Lei 221/67; Lei de Contravenções Penais, decreto-Lei 3688/41 entre outras, mas a partir de 1988 a tutela jurídica dos animais foi inserida como norma constitucional.

O artigo 225, parágrafo primeiro, inciso VII da Constituição Federal estabelece que incumbe ao Poder Público, proteger a fauna e a flora, vedadas, na forma da lei, as práticas que coloquem em risco sua função ecológica, provoquem a extinção de espécies ou submetam os animais à crueldade. 


\subsection{Proteção jurídica aos animais na esfera penal}

O decreto 16.590 de 1924 que regulamentava as Casas de Diversões Públicas, trouxe uma série de ações relacionadas à proteção dos animais contra violência, como a proibição das corridas de touro, brigas de galo e brigas de canários.

Posteriormente, o decreto 24.645 de 1934 especificou uma série de condutas que eram consideradas maus tratos e regulamentava pena de multa e reclusão de até 15 dias para aqueles que viessem a cometê-las. Apesar de estar revogado, ainda serve de parâmetro para a caracterização de maus tratos a animais no Brasil.

A Lei de Contravenções Penais de 1946 regulou em seu artigo 64 a proibição da crueldade contra os animais e estabeleceu penalidades para a prática, entretanto, não especificou as modalidades de crueldade a serem coibidas, trouxe apenas os termos crueldade e trabalho excessivo, um rol bem menor de condutas em relação àquele trazido pelo decreto $24.345 / 34$.

Dias (2000) relata que se levantou o questionamento de o fato da Lei de Contravenções Penais ter ou não revogado o decreto 24.345, mas jurisprudência da época firmou-se no sentido de que os preceitos contidos no artigo 64 compreendem, na sua quase totalidade, todas aquelas modalidades de crueldade contra os animais contidas no artigo $3 \%$ do decreto $24.645 / 34$.

Atualmente, a legislação brasileira de proteção aos animais é a Lei oㅜ 9605 de 1998, que define os animais domésticos, silvestres, nativos ou exóticos como possuidores do mesmo direito para a aplicação de penas relativas aos crimes de maustratos. A respectiva lei relata que praticar ato de abuso, maus-tratos, ferir ou mutilar animais silvestres, domésticos ou domesticados, nativos ou exóticos confere ao réu pena de detenção de três meses a um ano, e multa. Entretanto, ela não traz a definição do que sejam os maus-tratos ou crueldade.

Para Fiorillo (2013) a Lei 9605/98 consiste num minucioso regramento no sentido proteger a fauna, pela caracterização de diferentes situações e procura de fato trazer proteção à fauna enquanto bem ambiental, na medida em que, os animais não são sujeitos de direitos, porquanto a proteção do meio ambiente existe para favorecer 0 próprio homem e, somente por via reflexa, as demais espécies. 
A Lei de Crimes Ambientais em conjunto com a Constituição Federal, representam o ordenamento jurídico que protege os animais no Brasil, conferindo-lhes proteção jurídica, entretanto o animal não é considerado no Brasil um sujeito de direitos.

Embora não se reconheça a titularidade de direitos jurídicos aos animais, eles têm pelo menos o direito moral de não serem submetidos à crueldade. $O$ constituinte brasileiro optou eticamente em reconhecer o interesse do animal de não sofrer, quando esse sofrimento puder ser evitado, ao vedar práticas cruéis contra eles.

\subsection{Conceito de maus tratos aos animais}

Apesar da dificuldade de se conceituar claramente o que são maus tratos aos animais na legislação, existem autores que já trataram do assunto, uma definição que se mostra esclarecedora é a de que os maus tratos aos animais sejam "qualquer ato que contribui para a dor ou morte de um animal ou ameace o seu bem-estar" (AGNEW, 1998, p.179 apud SCHEFFER, 2019, p.13). Este conceito possui a vantagem de não limitar os maus tratos a animais somente a atos considerados ilegais pela legislação.

Para um melhor entendimento do que são os maus tratos aos animais, o Conselho Regional de Medicina Veterinária de São Paulo (CRMV-SP), em seu Guia Prático para Avaliação Inicial de Maus a Animais Domésticos de 2018 conceitua maustratos em dois aspectos: os maus tratos intencionais e os maus tratos por negligência, 0 primeiro é tido como ato que têm a intenção de causar dano físico ou psicológico ao animal, como a agressão ou crueldade aplicada diretamente ao animal. O segundo é tido como ato negligente, quando por omissão do responsável, não são ofertados os cuidados básicos como: água, alimento, abrigo. Fatores essenciais à manutenção da saúde e bem-estar dos animais.

Em âmbito Federal, o Conselho Federal de Medicina Veterinária (CFMV) editou a Resolução 1236/2018 a qual traz definições importantes acerca de ações prejudicais à saúde e bem-estar dos animais: 
Art. 2 ํ Para os fins desta Resolução, devem ser consideradas as seguintes definições:

II - maus-tratos: qualquer ato, direto ou indireto, comissivo ou omissivo, que intencionalmente ou por negligência, imperícia ou imprudência provoque dor ou sofrimento desnecessários aos animais;

III - crueldade: qualquer ato intencional que provoque dor ou sofrimento desnecessários nos animais, bem como intencionalmente impetrar maus tratos continuamente aos animais;

IV - abuso: qualquer ato intencional, comissivo ou omissivo, que implique no uso despropositado, indevido, excessivo, demasiado, incorreto de animais, causando prejuízos de ordem física e/ou psicológica, incluindo os atos caracterizados como abuso sexual;

$\mathrm{XI}$ - corpo de delito - conjunto de vestígios materiais resultantes da prática de maus-tratos, abuso e/ou crueldade contra os animais;

Art. $5^{\circ}-$ Consideram-se maus tratos:

[...] III - agredir fisicamente ou agir para causar dor, sofrimento ou dano ao animal;

IV -abandonar animais; [...]

Apesar do avanço social no julgamento moral e jurídico dos maus tratos aos animais, existe um grande aliado para que esta prática perdure, que é o interesse econômico ligado a manifestações culturais que fazem uso de animais para entretenimento, algumas vezes aplicando-Ihes manobras agressivas, e com o apoio do poder público, como no caso das vaquejadas.

\subsection{Maus tratos aos animais ocorridos na vaquejada}

O Regulamento Geral de vaquejada de 2017 - 2018 prevê em seu artigo 19 que "só será válida a pontuação, se o boi se soltar completamente entre as faixas de pontuação e, ao se firmar, estiver entre elas" (ASSOCIAÇÃO BRASILEIRA DE VAQUEJADA, 2016. p.9). Entende-se os termos: "se soltar completamente" e "se firmar" como o ato de o boi perder completamente o contato das patas com o chão e em seguida levantar-se entre as faixas após a derrubada para que valha a pontuação.

A derrubada é feita através de um puxão contrário ao sentido em que o boi está correndo, a força é tamanha que é capaz de derrubar o animal pesado. As manobras violentas de tracionar e torcer a cauda do boi, bem como o tombamento, podem acarretar severas lesões nos bovinos, pois a cauda constitui a continuidade da coluna 
vertebral, dotada de terminações nervosas, além do trauma dos órgãos internos com as paredes internas do corpo do boi ocasionado pela queda. Portanto é muito provável que haja aplicação de dor e sofrimento ao animal para se obter a pontuação na vaquejada.

Conforme parecer técnico de Irvênia Luiza de Santis Prada, citado pelo Ministro Barroso no acórdão da ADI 4983/CE, tem-se que:

Ao perseguirem o bovino, os peões acabam por segurá-lo fortemente pela cauda (rabo), fazendo com que ele estanque e seja contido. A cauda dos animais é composta, em sua estrutura óssea, por uma seqüência de vértebras, chamadas coccígeas ou caudais, que se articulam umas com as outras. Nesse gesto brusco de tracionar violentamente o animal pelo rabo, é muito provável que disto resulte luxação das vértebras, ou seja, perda da condição anatômica de contato de uma com a outra. Com essa ocorrência, existe a ruptura de ligamentos e de vasos sangüíneos, portanto, estabelecendo-se lesões traumáticas. Não é rara a desinfeção (arrancamento) da cauda, de sua conexão com o tronco. Como a porção caudal da coluna vertebral representa continuação dos outros segmentos da coluna vertebral, particularmente na região sacral, afecções que ocorrem primeiramente nas vértebras caudais podem repercutir mais para frente, comprometendo inclusive a medula espinhal que se acha contida dentro do canal vertebral. Esses processos patológicos são muito dolorosos, dada a conexão da medula espinhal com as raízes dos nervos espinhais, por onde trafegam inclusive os estímulos nociceptivos (causadores de dor). Volto a repetir que além de dor física, os animais submetidos a esses procedimentos vivenciam sofrimento mental. A estrutura dos eqüinos e bovinos é passível de lesões na ocorrência de quaisquer procedimentos violentos, bruscos e/ou agressivos, em coerência com a constituição de todos os corpos formados por matéria viva. Por outro lado, sendo o "cérebro", o órgão de expressão da mente, a complexa configuração morfo-funcional que exibe em eqüinos e bovinos é indicativa da capacidade psíquica desses animais, de aliviar e interpretar as situações adversas a que são submetidos, disto resultando sofrimento (PRADA, 1999 apud STF, 2016, p. 26).

Observa-se através do parecer técnico que o manejo do boi pela cauda traz consequências nocivas à saúde do animal, tais como: fraturas, traumatismos, deslocamento da articulação da cauda ou até mesmo a sua amputação.

O ministro Barroso em seu voto vista no acórdao da ADI 4983/CE (STF, 2016) considera que os gestos bruscos de tracionar e torcer a cauda do boi, bem como seu tombamento, praticados na vaquejada a tornam, por si só, uma prática cruel. Nenhuma regulamentação seria capaz de evitar a crueldade porque a vaquejada é caracterizada 
pela puxada do boi pela cauda e posterior derrubada do animal e toda regulamentação que impeça o vaqueiro de tracionar, torcer o rabo do boi e o derrubar descaracterizaria a própria vaquejada, fazendo com que ela fosse extinta.

A Lei de Crimes Ambientais em seu artigo 32 proíbe os maus-tratos, ferimentos e mutilações a animais, já a Resolução 1236/2018 do Conselho Federal de Medicina Veterinária define crueldade como qualquer ato intencional que provoque dor ou sofrimento desnecessários aos animais. Torna-se evidente a semelhança entre os conceitos trazidos nesses dispositivos e o comportamento do vaqueiro em relação ao animal na prática das vaquejadas. Na qual se têm atitudes humanas que infligem dor, sofrimento e até mutilações aos animais. Representadas pela tração, puxada da cauda e derrubada do boi, tornando a vaquejada uma prática cruel.

\section{AS DECISÕES DO STF ACERCA DOS MAUS TRATOS EM COMPETIÇOES COM ANIMAIS}

A corte do STF já se posicionou anteriormente em matérias semelhantes à vaquejada, onde se encontrava o aparente conflito entre o direito ao meio ambiente ecologicamente equilibrado e o direito à manifestação cultural. Abordar-se-á o posicionamento protecionista do Supremo em duas práticas já declaradas inconstitucionais: a Farra do Boi e a Rinha de Galo.

Ao tratar da Farra do Boi em 1997, no Recurso Extraordinário (RE) 153.531/SC, - STF utilizou da técnica de ponderação entre a manifestação cultural e o meio ambiente para a solução do conflito, onde se predominou o entendimento a favor de vedar práticas cruéis com animais mesmo que elas possuam o aspecto cultural. Ressalta-se que apesar de as regras serem diferentes, a farra do boi utilizava bovinos assim como a vaquejada. $O$ acórdão proferido nesta ação relatava que:

A obrigação de o Estado garantir a todos o pleno exercício de direitos culturais, incentivando a valorização e a difusão das manifestações, não prescinde da observância da norma do inciso VII do artigo 225 da Constituição Federal, no que veda prática que acabe por submeter os animais à crueldade. Procedimento discrepante da norma constitucional, denominado "farra do boi" (STF, 1997, p 01). 
As rinhas de galo constituem outra prática relevante já abordada pelo Supremo, essa denota mais o aspecto esportivo que o cultural, traz em sua essência a não interação do homem com o animal, onde os animais digladiam-se dentro de um ringue podendo chegar até à morte de uma das aves. Dias descreve a rotina ocorrida nas brigas de galo:

Os galos entram no rodo calçados com esporas postiças de metal e bico de prata (o bico de prata serve para machucar mais ou para substituir o bico já perdido em luta). A luta dura $1 \mathrm{~h} 15$, com quatro refrescos de $5 \mathrm{~m}$. Se o galo é tucado (recebe golpe mortal) ou é meio-tucado (está nocaute), a platéia histérica aposta lambujas, que são apostas com vantagens para o adversário. (DIAS, 2000 p.79)

$\mathrm{Na}$ ADI 2514/SC julgada em 2005, o STF reconheceu a inconstitucionalidade das brigas de galo, por considerá-las cruéis com os animais envolvidos, segue o trecho do julgamento:

A sujeição da vida animal a experiências de crueldade não é compatível com a Constituição do Brasil. Precedentes da Corte. Pedido de declaração de inconstitucionalidade julgado procedente. (ADI 2514/SC, julgada em 29/6/2005).

Em 2011 houve uma nova decisão do Supremo através da ADI 1856/RJ, questionando constitucionalidade da briga de galos desta vez prevista na Lei fluminense 2895/98, o Tribunal levou em consideração a tipificação do crime de maus tratos a animais previstos na lei de crimes ambientais e a norma constitucional de vedação à crueldade prevista no art. 225. O entendimento da matéria pelo do STF pode ser percebida, através do texto do acórdão:

A promoção de briga de galos, além de caracterizar prática criminosa tipificada na legislação ambiental, configura conduta atentatória à Constituição da República, que veda a submissão de animais a atos de crueldade, cuja natureza perversa, à semelhança da "farra do boi" (RE 153.531/SC), não permite sejam eles qualificados como inocente manifestação cultural, de caráter meramente folclórico (ADI 1.856/RJ, julgada em 26/5/2011). 
Nota-se que a lei de crimes ambientais equiparou os animais, silvestres, domésticos ou domesticados num só contexto e garantiu-lhes o direito de não serem abusados. Para Gordilho (2009) à luz da Constituição de 1988, os animais possuem pelo menos uma posição mínima de direito: a de não serem submetidos a tratamentos cruéis, a práticas que coloquem em risco a sua função ecológica ou que ponham em risco a preservação de sua espécie.

Extrai-se que o Supremo Tribunal Federal tem se posicionado de maneira biocêntrica, na qual predomina a ideia de que todos os seres vivos merecem ter suas vidas respeitadas. Consequentemente tem tomando medidas desfavoráveis às normas infraconstitucionais que manifestem interesse em tutelar práticas violentas contra animais sob o pretexto de garantir o acesso à cultura.

\subsection{Análise da vaquejada no Acórdão da ADI 4983/CE}

O Estado do Ceará, na tentativa de regulamentar a vaquejada em âmbito estadual, deu origem à Lei 15.299/13. Diante da suspeita de maus tratos aos animais na prática regulamentada, a P.G.R. interpôs junto ao STF a ADI 4983/CE. O relator Ministro Marco Aurélio descreve, em seu voto no acórdão, a fundamentação para a crueldade aos animais em vaquejada:

Consoante asseverado na inicial, o objetivo é a derrubada do boi pelos vaqueiros, o que fazem em arrancada, puxando-o pelo rabo [...] o autor juntou laudos técnicos que demonstram as consequências nocivas à saúde dos bovinos decorrentes da tração forçada no rabo, seguida da derrubada, tais como fraturas nas patas, ruptura de ligamentos e de vasos sanguíneos, traumatismos e deslocamento da articulação do rabo ou até o arrancamento deste, resultando no comprometimento da medula espinhal e dos nervos espinhais, dores físicas e sofrimento mental (STF, 2016, p.5).

Ao decidir sobre a matéria, o STF posicionou-se acirradamente a favor da inconstitucionalidade da lei 15.299 que regulava a vaquejada, com seis votos a favor e cinco votos contra, demonstrando a complexidade do tema. 
O primeiro voto divergente no acórdão partiu do Ministro Edson Fachin (STF, 2016) o qual reiterou que se faz necessário considerar a vaquejada como uma realidade enfrentada na zona rural e que a proibir seria enxergar a realidade apenas sob a ótica unilateral urbana. E que a competição seria uma forma de os vaqueiros reproduzirem e avaliarem suas técnicas de manejo com o gado, ações rotineiras do serviço no campo, portanto não haveria razão para torná-la inconstitucional.

O Ministro Gilmar Mendes (STF, 2016) acompanhou o voto divergente ao considerar que a inconstitucionalidade da vaquejada ensejaria na ausência de regulamentação e consequentemente na clandestinidade da prática. Relatou também sobre a importância da norma no sentido de nivelar a conduta dos vaqueiros no trato com os animais e na implementação de ações para promover o bem-estar animal as quais mitigariam a possibilidade de sofrimento. Por fim ressaltou que a vaquejada difere da farra do boi e da rinha de galo pelo seu aspecto esportivo enquanto que as duas práticas anteriores tinham por finalidade torturar o animal a ponto de matá-lo.

Entretanto, o Ministro Barroso (STF, 2016) considerou que o argumento da clandestinidade sob pena de dano maior aos animais não merece prosperar, uma vez que o julgador não pode decidir uma matéria primando pela não observância do ordenamento, uma vez que delitos como estupros e homicídios continuam a existir, mas nem por isso o julgador deve deixar de se posicionar contra eles.

O Ministro Barroso (STF 2016) reiterou que interpretação constitucional acerca da vaquejada de fato impõe um maior desafio à corte em relação às outras práticas, pois ela se diferencia da farra do boi e da rinha de galos por essas terem a crueldade explícita, de modo que não lhes restaram dúvidas sobre o assunto. Enquanto na vaquejada, o sofrimento não é tão evidente, pois os animais apresentam estar em bom estado de saúde antes e depois das provas, levando a crer que possa não existir crueldade alguma. Mas esclarece que:

Mesmo nas situações em que os danos físicos e mentais não sejam visíveis de imediato, a olho nu, há probabilidade de sequelas graves que se manifestam após o evento. De todo modo, a simples potencialidade relevante da lesão já é apta a deflagrar a incidência do princípio da precaução (STF, 2016 p.2). 
O Ministro Lewandowski (STF, 2016), considerou que se deve reconhecer que todos os seres vivos são interligados e cada forma de vida tem valor, independentemente do uso humano. Portanto concordou com o princípio da precaução e do cuidado, e ainda destacou a prevalência do princípio "in dubio pró natura" em litígios que envolvam matéria ambiental.

Compreende-se que apesar de a vaquejada possuir características que possam distanciá-la da farra do boi e da rinha de galo como, por exemplo, o aparente bem-estar animal antes e depois das provas. Ainda assim não constitui prova suficiente de que a saúde do animal está sendo resguardada durante a torção da cauda e a derrubada do boi. Portanto, diante da possibilidade do dano ambiental, deve-se adotar o princípio da precaução para que ele não ocorra.

O Ambientalista Fiorillo (2013) ratifica que o princípio da precaução afirma que a falta de certeza científica não deve ser usada como meio de postergar a adoção de medidas preventivas, quando houver ameaça séria de danos irreversíveis ao meio ambiente.

O Ministro Teori Zavascki (STF, 2016) posicionou-se contrário à vedação da vaquejada, defendendo que a lei procurava regulamentar a prática exatamente para afastar dela tratamentos cruéis e que a vaquejada pode ser exercida desde que cumpra as determinações legais que garantam o bem-estar do animal, portanto não haveria por que ser proibida. Verifica-se que o Ministro Zavascki deixou de considerar, em seu voto, que a derrubada do animal com as quatro patas voltadas para cima consiste em ato cruel.

Relatou ainda que o alcance da matéria questionada pela ADI se restringia apenas à Lei 15.299/13 do Ceará e não à prática da vaquejada nos demais Estados. Conforme o trecho do seu voto:

De modo que, aqui, não se está discutindo diretamente - pelo menos numa ação direta nem seria cabível - a constitucionalidade da vaquejada em si mesma. Nós estamos discutindo, aqui, a constitucionalidade da Lei 15.299 , de janeiro de 2013, que veio regulamentar a vaquejada como atividade desportiva e cultural no Estado do Ceará (STF, 2016, p.2). 
Em sentido contrário a este entendimento o Ministro Marco Aurélio afirma em seu voto que:

O sentido da expressão "crueldade" constante da parte final do inciso VII do $\S 10$ do artigo 225 do Diploma Maior alcança, sem sombra de dúvida, a tortura e os maus-tratos infligidos aos bovinos durante a prática impugnada, revelando-se intolerável, a mais não poder, a conduta humana autorizada pela norma estadual atacada. No âmbito de composição dos interesses fundamentais (STF, 2016, p.6)

Depreende-se da decisão do Relator que a matéria alvo da decisão do STF foi a colisão de direitos fundamentais: de um lado o direito da coletividade a um meio ambiente ecologicamente vedando a crueldade contra animais e do outro o direito à manifestação cultural e não somente a matéria da Lei 15.299 do Ceará.

Gordilho e Figueiredo (2016) definem que em se tratando de Ação Direta de Inconstitucionalidade, o STF brasileiro adota a Teoria da Transcendência dos Motivos Determinantes, de modo que o julgado terá efeito erga omnes e vinculante em relação aos órgãos do Poder Judiciário e da Administração Pública Federal, estadual e municipal de modo que, toda e qualquer lei nacional, estadual ou municipal com conteúdo semelhante é inválida.

A Ministra Rosa Weber (STF, 2016) acompanhou o relator e destacou que a Constituição confere valor também às formas de vidas não humanas, no caso, os seres sencientes, e que apesar de existir a garantia do direito à manifestação cultural, também é vedada a crueldade contra animais, e no caso em tela a crueldade é intrínseca à vaquejada.

O Ministro Celso de Mello (STF, 2016) opinou pela inconstitucionalidade da vaquejada e acrescentou que nem sequer pode qualificá-la como atividade desportiva, prática cultural ou expressão folclórica diante do que ela se propõe. Pois o sofrimento desnecessário dos animais decididamente não constitui expressão de atividade cultural por repugnar aos padrões civilizatórios. E que a regulamentação seria incorrer em crime ambiental definido na Lei 9.605/1998.

O voto decisivo ficou a cargo da Ministra Carmen Lúcia (STF, 2016), onde ela considerou que o processo evolutivo das civilizações, apesar de terem suas culturas 
enraizadas, ainda possuem capacidade de transformação diante de outros modos de ver a vida, com o enfoque voltado não somente para o ser humano. De modo que não são mais toleráveis atividades que promovam o sofrimento animal para fins de entretenimento, como por exemplo permitir a derrubada do boi pelo rabo, submetendo efetivamente os animais à crueldade e maus-tratos.

Ao tratar da vaquejada, a jurisprudência do STF vem seguindo a mesma linha de pensamento dos julgados anteriores em relação a práticas culturais que envolvam maus tratos a animais, como a Farra do Boi e a Rinha de Galo, demonstrando sua tendência protecionista ao estabelecer a predominância do interesse do animal de não sofrer em relação às manifestações culturais consideradas cruéis.

\subsection{A Lei 13.364/16 e EC 96/17 sob a ótica constitucional}

A inconstitucionalidade da Lei 15.299/13 declarada pelo STF não agradou aos simpatizantes da vaquejada, de modo que houve o questionamento se a ADI proibiu o evento nacionalmente ou tão somente invalidou a Lei em âmbito Estadual.

Realça-se que por se tratar de ADI em sede de controle concentrado, ainda que tenha abordado apenas a Lei estadual, subsistem os efeitos erga omnes os quais transcendem os limites territoriais do Estado que editou a norma atacada conforme 0 disposto no art. 102, § 2º da Constituição da República:

$\S 2^{\circ}$ As decisões definitivas de mérito, proferidas pelo Supremo Tribunal Federal, nas ações diretas de inconstitucionalidade e nas ações declaratórias de constitucionalidade produzirão eficácia contra todos e efeito vinculante, relativamente aos demais órgãos do Poder Judiciário e à administração pública direta e indireta, nas esferas federal, estadual e municipal (CF, 1988).

Essa transcendência territorial decorre da força vinculativa das decisões do STF no controle concentrado de constitucionalidade das leis, de modo a expandir os efeitos da decisão em todo o território nacional. 
Diante da questão, houve uma reação legislativa no sentido contornar a decisão do STF e conferir legalidade à prática para que não houvesse questionamento judicial para impedir novos eventos.

Houve celeridade na aprovação do Projeto de Lei 24/2016 da Câmara, que deu origem à Lei $13.364 / 16$ a qual elevou o rodeio, a vaquejada e as respectivas expressões artístico-culturais à condição de manifestação cultural nacional e de patrimônio cultural imaterial.

Para evidenciar o ativismo político como forma de tornar sem efeito a decisão do STF através de Lei Federal, é válido ressaltar que a legislação brasileira prevê regramento próprio, para reconhecer e preservar o patrimônio cultural de natureza imaterial que consiste no Decreto no 3551 de 2000 conforme o trecho:

O PRESIDENTE DA REPÚBLICA, no uso da atribuição que lhe confere 0 art. 84, inciso IV, e tendo em vista o disposto no art. 14 da Lei no 9.649 , de 27 de maio de 1998,

DECRETA: Art. 1ํ. Fica instituído o Registro de Bens Culturais de Natureza Imaterial que constituem patrimônio cultural brasileiro.

$[\ldots] \S 2^{\circ}$. A inscrição num dos livros de registro terá sempre como referência a continuidade histórica do bem e sua relevância nacional para a memória, a identidade e a formação da sociedade brasileira[...]

[...]Art. 3‥ As propostas para registro, acompanhadas de sua documentação técnica, serão dirigidas ao Presidente do Instituto do Patrimônio Histórico e Artístico Nacional - IPHAN, que as submeterá ao Conselho Consultivo do Patrimônio Cultural[...]

[...]Art. 7ํ․ O IPHAN fará a reavaliação dos bens culturais registrados, pelo menos a cada dez anos, e a encaminhará ao Conselho Consultivo do Patrimônio Cultural para decidir sobre a revalidação do título de "Patrimônio Cultural do Brasil"

Parágrafo único. Negada a revalidação, será mantido apenas o registro, como referência cultural de seu tempo[...](Decreto 3551, 2000)

O decreto não retira a autonomia legislativa para se reconhecer uma atividade cultural através de Lei, entretanto estabelece de maneira procedimental e com amplo estudo as deliberações sobre registro de manifestações culturais de natureza imaterial integrante do patrimônio cultural brasileiro, inclusive com avaliações periódicas para considerar se determinada prática permanece ou não como elemento cultural de uma região, a opção do legislador em definir o aspecto cultural por Lei evidencia o interesse político/econômico desta. 
Apesar de a Lei 13.364/16 conferir característica cultural à vaquejada, o STF entendeu através do julgado da ADI 4983/CE que a proibição da crueldade prevalece sobre a proteção cultural, ou seja, a lei sozinha não remediava o entendimento do Supremo. Portanto Congresso Nacional alterou a Constituição, com a previsão expressa de que são permitidas práticas desportivas que utilizem animais, desde que sejam manifestações culturais. A EC 96/17 somada à Lei 13.364/16 garantiu viés constitucional à vaquejada, porém de forma precária, pois não houve estudo aprofundado e não considerou cruéis as manobras bruscas que ocorrem nas arenas.

Ressalta-se que a proposta de emenda constitucional $n=50 / 2016$ que deu origem à EC 96/17 não menciona em nenhum momento os pareceres técnicos contrários à vaquejada citados na decisão do STF, tampouco menciona novo parecer técnico trazendo alguma forma de normatizar a atividade sem que haja crueldade com animais.

Embora efetivada na Constituição, a EC $96 / 17$ possui característica viciosa que a torna incompatível com os ditames constitucionais, tal qual a violação ao art. $60 \S 4^{\circ}$ da CF a qual dispõe que não é permitida a edição de emenda constitucional que acabe ou enfraqueça a forma federativa de Estado; o voto direto, secreto, universal e periódico; a separação dos Poderes e, por último e aplicado à matéria em questão, os direitos e garantias individuais.

Bonavides (2001) entende que o direito a um meio ambiente equilibrado constitui direito fundamental de terceira geração, fundado na solidariedade, de caráter coletivo ou difuso, dotado do altíssimo teor de humanismo e universalidade.

$\mathrm{O}$ art. 225 da Constituição define que todos têm o direito a um meio ambiente equilibrado, tal equilíbrio pressupõe a vedação de crueldade contra animais e define que a preservação do ecossistema é dever de todos. Portanto nas questões ambientais, o indivíduo é considerado detentor deste direito e ao mesmo tempo tem o dever de resguardá-lo para as futuras gerações.

$\mathrm{Na}$ opinião de Moraes (2017) o Direito Constitucional protege direitos de terceira geração os chamados direitos de solidariedade ou fraternidade, que englobam o direito a um meio ambiente equilibrado. Ou seja, esses direitos não podem ser suprimidos, ainda que por emenda constitucional, sob pena de violar cláusula pétrea prevista no art. 60 §4 IV da Constituição. 
Pautado nessa máxima, o Fórum Nacional de Proteção e Defesa Animal propôs a ADI 5728/DF em 2017 para impugnar a totalidade do conteúdo a EC 96/17. A PGR manifestou-se nos autos e através do parecer da Procuradora Raquel Dodge resultou considerações importantes pertinentes ao conteúdo polêmico da Emenda constitucional:

A emenda constitucional contém uma ilogicidade insuperável: define como não cruéis as práticas desportivas se forem reconhecidas como manifestação cultural. Ocorre que a crueldade intrínseca a determinada atividade não desaparece pelo fato de uma norma jurídica a rotular como "manifestação cultural". A crueldade ali permanecerá, qualquer que seja o tratamento jurídico a ela atribuído e não há dúvida de que animais envolvidos em vaquejadas são submetidos a condições degradantes e sistemáticas de lesões e maus-tratos, as quais caracterizam tratamento cruel, que encontra vedação no art. $225, \S 1^{\circ}$, VII, da Constituição da República (PGR, 2018, p. 15).

Após o Parecer da PGE, algumas entidades ingressaram com pedido de Amicus Curiae, onde foram deferidos os pedidos da Associação Brasileira de Quarto de Milha e da Associação Protetora dos Animais do Distrito Federal e encontram-se para análise os pedidos da Associação Brasileira de Vaquejada e da Vegetarianismo Ético, Defesa dos Direitos dos Animais e Sociedade, os quais encontram-se conclusos para o Relator. O STF ainda não proferiu nenhuma decisão em relação a esta nova ADI que aborda a Vaquejada.

No ano corrente a Lei 13.364/16 recebeu alterações através da Lei 13.873 de setembro de 2019 a qual incluiu as provas de laço no rol de manifestações culturais e inseriu cuidados com o bem-estar dos animais como: assistência médico-veterinária, camada espessa de areia nas arenas e a obrigatoriedade do protetor de calda. Cabe enfatizar que o protetor de cauda não garante proteção total quanto à possibilidade de lesões, pois ainda se liga à estrutura da cauda do animal.

Conclui-se que o próprio legislador reconhece a potencialidade lesiva da vaquejada aos animais ao trazer modificações no regulamento ligadas à diminuição do sofrimento animal. Ou seja, em se tratando desta Lei descartou-se o princípio ambiental da precaução, onde se preferiu remediar o dano ao invés de preveni-lo. 
Ao observar a inviabilidade da EC 96/17 por afronta ao $\S 4^{\circ}$ do art. 60 tem-se que a Lei 13.364/2016 editada pela Lei 13.873/2019 também são inconstitucionais, pois juntas demonstram seu objetivo de desautorizar decisão do STF e viabilizar em âmbito nacional manifestações culturais que a Constituição considera ilícitas por legitimar crueldade contra animais.

\section{CONSIDERAÇÕES FINAIS}

Diante do que foi estudado ao comparar o aspecto cultural da vaquejada e o direito ao meio ambiente ecologicamente equilibrado, extrai-se que a prática possui aspecto cultural consolidado na região nordeste, entretanto, a forma de expressar esta cultura ocorre em desconformidade com a Constituição Brasileira, dá-se em desacordo com a legislação de crimes ambientais e também de maneira contraria às decisões do STF.

Para que seja garantido o direito à cultura relativo à vaquejada, pode-se praticála de maneiras alternativas, como: demonstrá-la em exposições artísticas, teatrais ou musicais sem o manuseio de animais, como já aconteceu nos circos. Desse modo remonta-se o passado, respeita-se a tradição sertaneja e não dá continuidade à prática que prejudique a saúde dos bovinos e equinos envolvidos.

Ressalta-se que argumentos como o acesso à cultura, geração de emprego e renda não sustentam por si só a continuidade da vaquejada. Pois atividades como a farra do boi e a rinha de galo já fizeram parte da cultura brasileira, eram legalmente aceitas e geravam movimentação de renda, entretanto nenhum desses argumentos foram capazes de torná-las moralmente aceitas diante do sofrimento que elas impunham aos animais envolvidos.

Atividades que envolvem animais são consideradas culturais e importantes para a sociedade, mas também devem evoluir, do contrário, ter-se-iam eternizadas práticas cruéis e nocivas à saúde dos animais, seres incapazes de reclamar a dor, mas com total aptidão para senti-la, os quais dependem exclusivamente da consciência humana para não receberem tratamentos cruéis. 
Diante do que foi estudado conclui-se que as normativas relacionadas à tutela da prática da vaquejada são incompatíveis com o Ordenamento Jurídico Pátrio, pois o constituinte originário fez esta reflexão no sentido de garantir que o homem tenha o direito e dever de não compactuar com práticas cruéis a animais ao reconhecer o direito ao meio ambiente ecologicamente equilibrado como direito fundamental e insuscetível de alteração.

\section{REFERÊNCIAS}

ASSEMBLEIA GERAL DAS NAÇÕES UNIDAS. Declaração Universal dos Direitos Humanos. Paris, 1948. Versão online. Disponível em: <https://nacoesunidas.org/wpcontent/uploads/2018/10/DUDH.pdf> Acesso em: 28 ago. 2019.

ASSOCIAÇÃO ALAGOANA DE CRIADORES DE CAVALO QUARTO DE MILHA ALQM. Vaquejada movimenta mais de 60 milhões. Disponível em:

$<$ http://gazetaweb.globo.com/gazetadealagoas/noticia.php?c=312390>Acesso em: 27 jun. 2019>.

ASSOCIAÇÃO BRASILEIRA DE VAQUEJADA - ABVAQ. Regulamento Geral da Vaquejada 2017 - 2018. De 29 de Dezembro de 2016. Dispõe sobre unificação de regras da vaquejada em todo o Brasil, via Associação Brasileira de Vaquejada, estabelece normas de realização dos eventos, de bem-estar animal, e define procedimentos e diretrizes garantidoras do bom andamento do esporte, através do controle e prevenção sanitário-ambientais, higiênico sanitárias e de segurança em geral. Disponível em: <

https://nucleos.nyc3.digitaloceanspaces.com/abvaq/documentos/regulamentogeraldeva quejada20172018.pdf> Acesso em 02 set. 2019.

BEZERRA, José Euzébio Fernandes. Retalhos do meu sertão. Rio de Janeiro: Leão do Mar, 1978.

BONAVIDES, Paulo. Curso de Direito Constitucional. São Paulo: $11^{\underline{a}}$ ed. Malheiros, 2001.

BRASIL. Constituição (1988). Constituição da República Federativa do Brasil de 1988. Brasília, DF: Presidência da República, [2016]. Disponível em:

http://www.planalto.gov.br/ccivil_03/Constituicao/Constituiçao.htm. Acesso em: 21 ago. 2019 
Decreto-Lei no 221/67, de 28 de fevereiro de 1967. Dispõe sobre a proteção e estímulos à pesca e dá outras providências. Disponível em: < https://presrepublica.jusbrasil.com.br/legislacao/109275/codigo-de-pesca-de-1967decreto-lei-221-67> . Acesso em: 02 out. 2019.

Decreto-Lei no 3.688/41, de 03 de outubro de 1941. Lei das Contravenções Penais. Disponível em: < http://www.planalto.gov.br/ccivil 03/decreto-lei/del3688.htm>. Acesso em: 02 out. 2019.

Decreto no 3.551, de 04 de agosto de 2000. Institui o Registro de Bens Culturais de Natureza Imaterial que constituem patrimônio cultural brasileiro, cria o Programa Nacional do Patrimônio Imaterial e dá outras providências. Disponível em: < http://www.planalto.gov.br/ccivil 03/decreto/D3551.htm>. Acesso em: 23 out. 2019.

Decreto no 16.590 , de 10 de setembro de 1924. Aprova o regulamento das casas de diversões públicas. Disponível em: < https://www2.camara.leg.br/legin/fed/decret/1920-1929/decreto-16590-10-setembro1924-509350-publicacaooriginal-1-pe.html>. Acesso em: 02 out. 2019

Decreto no 24.645, de 10 de julho de 1934. Estabelece medidas de proteção aos animais. Disponível em: < http://www.planalto.gov.br/ccivil 03/decreto/19301949/D24645.htm>. Acesso em: 02 out. 2019.

. Lei no 5.197, de 03 de janeiro de 1967. Dispõe sobre a proteção à fauna e dá outras providências. Disponível em: <http://www.planalto.gov.br/ccivil 03/leis/L5197.htm>. Acesso em: 02 out. 2019.

. Lei no 9605/98, de 12 de fevereiro de 1998. Dispõe sobre as sanções penais e administrativas derivadas de condutas e atividades lesivas ao meio ambiente, e dá outras providências. Disponível em: < http://www.planalto.gov.br/ccivil 03/leis/l9605.htm>. Acesso em: 03 out. 2019.

. Lei no 13.364, de 29 de novembro de 2016. Eleva o Rodeio, a Vaquejada, bem como as respectivas expressões artístico-culturais, à condição de manifestação cultural nacional e de patrimônio cultural imaterial. Brasília: Presidência da República, [2016]. Disponível em: <http://www.planalto.gov.br/ccivil 03/ ato20152018/2016/lei/L13364.htm>. Acesso em: 23 ago. 2019.

. Lei no 13.873, de 17 de setembro de 2019. Altera a Lei no 13.364, de 29 de novembro de 2016, para incluir o laço, bem como as respectivas expressões artísticas e esportivas, como manifestação cultural nacional, elevar essas atividades à condição de bem de natureza imaterial integrante do patrimônio cultural brasileiro e dispor sobre as modalidades esportivas equestres tradicionais e sobre a proteção ao bem-estar animal. Brasília: Presidência da República, [2019]. Disponível em: <http://www.planalto.gov.br/ccivil 03/ Ato2019-2022/2019/Lei/L13873.htm\#art2 > Acesso em: 29 set. 2019. 
. Procuradoria Geral da República. Parecer no 116.061/2018. Ação direta de inconstitucionalidade. EC 96/2017. Vaquejada. Ofensa à limitação material ao poder constituinte reformador. Questão já enfrentada pelo STF em sede de ADI. Parecer pelo conhecimento da ação e procedência do pedido. 03 de maio de 2018. Disponível em: < http://portal.stf.jus.br/processos/downloadPeca.asp?id=314274681\&ext=.pdf $>$. Acesso em: 23 out. 2019.

. Senado Federal. Emenda Constitucional no 96/2017 - Brasília, DF. Acrescenta $\S 7^{\circ}$ ao art. 225 da Constituição Federal para determinar que práticas desportivas que utilizem animais não são consideradas cruéis, nas condições que especifica. 06 de junho de 2017. Disponível em: < http://www.planalto.gov.br/ccivil 03/constituicao/Emendas/Emc/emc96.htm > Acesso em: 21 ago. 2019.

. Senado Federal. Proposta de Emenda Constitucional no 50/2016 - Brasília, DF. Propõe que práticas desportivas que utilizem animais não são consideradas cruéis, nas condições que especifica. 15 de fevereiro de 2017. Disponível em: < https://www.camara.leg.br/proposicoesWeb/fichadetramitacao?idProposicao=2140762> Acesso em: 21 ago. 2019.

. Supremo Tribunal Federal. Ação Direta de Inconstitucionalidade no. 1856/RJ - Brasília, DF. Direito administrativo e outras matérias de direito público | Meio Ambiente | Fauna. Relator: Min. Celso de Mello, 07 jul. 1998. Disponível em: < http://portal.stf.jus.br/processos/detalhe.asp?incidente=1718892> Acesso em: 22 out. 2019.

. Supremo Tribunal Federal. Ação Direta de Inconstitucionalidade no. 2514/SC - Brasília, DF. Direito administrativo e outras matérias de direito público | Controle de Constitucionalidade. Relator: Min. Eros Grau, 31 ago. 2001. Disponível em: $<$ http://portal.stf.jus.br/processos/detalhe.asp?incidente $=1966536$ > Acesso em: 22 out. 2019.

. Supremo Tribunal Federal. Ação Direta de Inconstitucionalidade no. 4983/CE - Brasília, DF. Direito administrativo e outras matérias de direito público | Controle de Constitucionalidade | Inconstitucionalidade Material. Relator: Min. Marco Aurélio, 18 jun. 2013. Disponível em:

$<$ http://portal.stf.jus.br/processos/detalhe.asp?incidente $=4425243>$ Acesso em: 22 ago. 2019.

. Supremo Tribunal Federal. Ação Direta de Inconstitucionalidade no. 5728/DF - Brasília, DF. Direito administrativo e outras matérias de direito público | Controle de Constitucionalidade. Relator: Min. Dias Toffoli, 13 jun. 2017. Disponível em: $<$ http://portal.stf.jus.br/processos/detalhe.asp?incidente=5208901 > Acesso em: 12 out. 2019. 
. Supremo Tribunal Federal. Inteiro Teor do Acórdão ADI 4983/CE.

VAQUEJADA - MANIFESTAÇÃO CULTURAL - ANIMAIS - CRUELDADE MANIFESTA - PRESERVAÇÃO DA FAUNA E DA FLORA - INCONSTITUCIONALIDADE. A obrigação de o Estado garantir a todos o pleno exercício de direitos culturais, incentivando a valorização e a difusão das manifestações, não prescinde da observância do disposto no inciso VII do artigo 225 da Carta Federal, o qual veda prática que acabe por submeter os animais à crueldade. Discrepa da norma constitucional a denominada vaquejada. [2016]. Disponível em: $<$ http://redir.stf.jus.br/paginadorpub/paginador.jsp?docTP=TP\&doclD=12798874> . Acesso em: 12 out. 2019.

. Supremo Tribunal Federal. Recurso Extraordinário 153.531-8 SC - Santa Catarina. Repercussão geral no Recurso Extraordinário. A obrigação constitucional do Estado de assegurar a todos os cidadãos o pleno exercício de direitos culturais, promovendo a apreciação e difusão de manifestações culturais, não exime o Estado de observar o dispositivo constitucional que proíbe o tratamento cruel de animais. Relator: Min. Marco Aurélio, 03 de junho de 1997. Disponível em:

$<$ http://redir.stf.jus.br/paginadorpub/paginador.jsp?docTP=AC\&doclD=211500 >. Acesso em: 21 out. 2019.

CASCUDO, Luís da Câmara. A vaquejada nordestina e sua origem. Natal: Fundação José Augusto, 1976.

COMISSÃO DE BEM-ESTAR ANIMAL - CRMV-SP. Guia Prático para Avaliação inicial de maus tratos a animais domésticos. De 15 de Outubro de 2018. Dispõe sobre a identificação de sinais de maus tratos em cães e gatos para o atendimento de denúncias por agentes públicos. Disponível em: < https://www.crmvsp.gov.br/arquivo legislacao/GUIA PRATICO PARA AVALIACAO IN ICIAL DE MAUS TRATOS A CAES E GATOS.pdf > Acesso em 05 out. 2019.

CONSELHO FEDERAL DE MEDICINA VETERINÁRIA - CFMV. Resolução no 1236. De 26 de outubro de 2018. Define e caracteriza crueldade, abuso e maus tratos contra animais vertebrados, dispõe sobre a conduta de médicos veterinários e zootecnistas e dá outras providências. Disponivel em: < http://portal.cfmv.gov.br/lei/index/id/903> Acesso em 05 out. 2019.

DIAS, Edna Cardozo. A tutela jurídica dos animais. Belo Horizonte: Tese de Doutorado apresentada ao Curso de Doutorado da Faculdade de Direito da Universidade Federal de Minas Gerais, 2000. Disponível em: $<$ https://www.passeidireto.com/arquivo/19996385/tutela-juridica-dos-animais >. Acesso em 03 out. 2019.

ESTADO DO CEARÁ. Lei no 15.299, de 08 de janeiro de 2013. Regulamenta a Vaquejada como prática desportiva e cultural no Estado do Ceará. Fortaleza: Assembleia Legislativa, [2013]. Disponível em: 
$<$ http://imagens.seplag.ce.gov.br/PDF/20130115/do20130115p01.pdf\#page=15> . Acesso em: 22 ago. 2019.

FERNANDES, José Ricardo Oriá. A cultura no ordenamento constitucional brasileiro: impactos e perspectiva. Ensaios sobre impactos da Constituição Federal de 1988 na sociedade brasileira. Brasília, vol. 1, n. 2. 2008. Disponível em $<$ https://www2.camara.leg.br/atividade-legislativa/estudos-e-notas-tecnicas/publicacoesda-consultoria-legislativa/livros-eletronicos/vol-1.pdf.> Acesso em: 23 ago. 2019. FIORILLO, Celso Antônio Pacheco. Curso de direito ambiental brasileiro. São Paulo: 14를 ed. Saraiva, 2013.

GORDILHO, Heron J. S. Abolicionismo animal. Salvador: Evolução, 2009.

GORDILHO, Heron; FIGUEIREDO, Francisco. A Vaquejada à luz da constituição federal. Revista de biodireito e direito dos animais, Curitiba, v. 2, n. 2, 2016.

MORAES, Alexandre de. Direito Constitucional. São Paulo: 33ª ed. Atlas, 2017.

NACONECY, Carlos Michelon. Ética \& animais um guia de argumentação filosófica. Porto Alegre: Edipucrs, 2006.

SCHEFFER, Gisele Kronhardt. Diálogos de direito animal. Porto Alegre: Ed. Canal Ciências Criminais, 2019. Disponível em: < https://www.passeidireto.com/arquivo/66104766/dialogos-de-direito-animal-giselekronhardt-scheffer-2019>. Acesso em 01 out de 2019. 